\title{
Consequences of Urbanization on Surface Water bodies Water Quality along the Rural-Urban and Transition Zones of Bengaluru
}

\author{
C. Dhanush* and A.S. Devakumar \\ Department of Forestry and Environmental Sciences, GKVK, UAS, Bengaluru, India \\ *Corresponding author
}

\begin{tabular}{|c|}
\hline Keywords \\
\hline $\begin{array}{l}\text { Surface water } \\
\text { quality, Drinking } \\
\text { water quality, } \\
\text { Irrigation water } \\
\text { quality, Livestock } \\
\text { water quality }\end{array}$ \\
\hline Article Info \\
\hline $\begin{array}{l}\text { Accepted: } \\
\text { 15 November } 2019 \\
\text { Available Online: } \\
\text { 10 December } 2019\end{array}$ \\
\hline
\end{tabular}

\section{A B S T R A C T}

Water contamination is one of the many consequential concerns of urbanisation that need immediate attention in most cosmopolitan cities. In Bengaluru, one of the fast growing metropolitan cities in India, most of the water bodies are contaminated. Thus it is critical to ascertain the extent of as well the source of contamination. This study is an attempt to see the water quality in the agroecosystems along rural urban transition zones (RUT) of Bengaluru. Water quality is determined based on specific physical, chemical and biological surrogates in both surface water $(n=30)$ bodies located within one kilometer radius of agriculture lands. The mean water quality index of urban surface water suggest that it is not suitable for drinking but, fairly suitable for irrigation and industrial use (C3 and $\mathrm{C} 4$ category), while in the transition and rural area it is again not suitable for drinking purpose but suitable for irrigation and industrial use (C2 category). Piper tri-linear diagram indicate that majority of the surface water samples belong to mixed $\mathrm{Ca}^{2+}-\mathrm{Mg}^{2+}-\mathrm{Cl}^{-}-\mathrm{SO}_{2}{ }^{4-}$ type. Results indicate that water quality in the RUT is depilating and cannot be used for human consummations. Hence there is an immediate need to put water resource management in place.

\section{Introduction}

Urbanization is a contemporary global trend resulting from population growth and migration in search for job opportunities, better education, infrastructure and security. It raises the concentrated demand for food, energy and construction materials at specific locations and leads to the establishment of a rural-urban gradient with targeted flows of basic natural and human resources reflecting major changes in ecosystem services. In developing countries like India, China and Nigeria will account for $35 \%$ of the projected growth of the world's urban population between 2018 and 2050 (UN DESA, 2019); in this process, cities may eventually occupy an area equivalent to 7 percentage of the world's arable land, compared with 3percentageduring 2005 (Angel et al., 2005). 
Mega cities, urban conglomerations with a population of more than 10 million inhabitants, represent the most advanced state of urbanization. Their effects on surrounding agroecosystems and even at the global ecological scale (Seto et al., 2013) are evident in many Asian cities such as Beijing and Jakarta, but also in rapidly growing Indian cities such as Mumbai and Bengaluru. In the Global South, megacities are growing especially rapidly (Sorensen and Okata, 2010). Three of the world's 19 cities with more than 10 million inhabitants are located in India (Delhi, Mumbai, and Kolkata) and Bengaluru, Hyderabad and Chennai are likely to pass this threshold in the near future (Taubenböcket al., 2008). Bengaluru has been the fastest-growing Indian city over the last 40 years (Narayana, 2011).

Global demand for water is increasing at one per cent annually as a function of population growth and economic development (WWAP, 2018). The UN estimates of waste water production of about $1,500 \mathrm{~km}^{3}$ year ${ }^{-1}$, six times more water that exists in all the rivers of the world (WWAP, 2003), suggests that the global water scarcity is largely due to deterioration in the quality rather than the physical scarcity of the resource. In India alone, currently 600 million people face high to extreme water shortage, with around two lakh people dying every year due to inadequate access to potable water (NitiAayog, 2018).

Bengaluru, also known as Silicon Valley and Information Technology corridor of India, occupies an area of $741 \mathrm{~km}^{2}$. Bengaluru was a small sustainable green city until the time of economic liberalization, which led to industrial revolution in 1990's, and advent of the Information and communication sectors in 2000's. Due to these changes a sudden spurt in population is seen which increased drastically from three to eight million by 2011 . The rapid urbanization has brought in fundamental changes in land use (Ramachandra et al., 2012), agriculture and water. It is important to note that all these three natural resources are closely inter-connected and have serious implications on health, livelihood and economy.

The impact on ground water (both quantity and quality) is very critical, as Bengaluru relies heavily on ground water resources. Ground water contributes to fifty percent of the urban requirements and eighty percent of the drinking water in rural areas (Hunse, 2008). However, urbanization has drastically depleted the ground water resources in the past few decades. As per records, till 1960 there were 262 water bodies in Bangalore and today it hasonly around 81, of which 34 are recognized as live lakes (Anon, 2017). In the urban Bangalore, water bodies use to cover about 5\% of the land (Anon, 2017) which has diminished to 3.4 per cent by 1973 , to less than 1 per cent by 2013 (Goswami, 2017). Along with the decreasing water levels nearly 85 per cent of the water bodies are severely polluted (Anon, 2017). The demand for water in expanding Bengaluru is increasing every day but the quantity and quality of the surface and ground water are decreasing rapidly. Agriculture is one such sector that gets affected as well as affects the water both in terms of quantity and quality. Globally, among prominent factors that contaminate water agriculture is considered to be the most prevalent one. Majority of nutrient emissions originate from agriculture(WWAP, 2019). More than $80 \%$ of sewage in developing countries is discharged untreated that pollute rivers, lakes and coastal areas (WWAP, 2019).

Thus increasing agriculture productions and increasing wastewater effluents associated with increasing population has affected the surface water bodies both in urban and adjoining rural areas of Bengaluru. However, there is no systematic analysis of water quality 
across the rural, urban and the transition regions of Bengaluru cosmopolitan city to that delineate the role of agriculture in water pollution. In this context present study is an attempt to assess the influence of Agriculture on water quality in the RUT zones.

\section{Materials and Methods}

\section{Study area}

To understand the water quality status in rural urban transition, we laid two transacts in north and south Bengaluru by using the survey stratification index (Hoffmann et al., 2017). The Northern transect (N-transect) is a rectangular stripe of $5 \mathrm{~km}$ width and $50 \mathrm{~km}$ length, as shown in Figure 1.

The lower part of this transect represent urban Bangalore, and the upper part represent rural villages and the middle portion is considered as transition zone. The Southern transect (Stransect) is a polygon covering a total area of ca. $300 \mathrm{~km}^{2}$ (Figure 1). The zonation in this transect into urban, rural and transition zones is same as explained above in case of $\mathrm{N}$ transect.

\section{Site selection}

The list of villages and urban areas is compiled using satellite images from Bhuvan website, a mapping tool. Altogether, there were 93 villages and urban units in the $\mathrm{N}$ transect and 98 villages and urban units in the S-transect. The urban units and village classification in transect is primarily based on percentage of built-up area in a defined perimeter around a village and linear distance between a village center and the city center. Both components, building density and distance, were combined for calculate the Survey Stratification Index to classify RUT (Hoffmann et al., 2017). From this a total of 36 (six sites in all the three identical zones of both transects) villages and urban units were randomly selected to assess the water quality status in rural urban interface.

\section{Water sample collection}

In identical zones of RUT, rural and transition zone shares 12 villages each and 12 unban units (six sites in all the three identical zones of both transects)were selected total of 60 water samples were collected during October 2017 and October 2018.

In each identical zone 10 water ponds (five water pond sampled in all the three identical zones of both transects) were collected to quantify the surface water quality status of Agroecosystem in RUT (sample location details are given in Supplementary Table 2). Water bodies (mostly ponds) were selected with in one kilometer radius of agricultural activities in the villages and in urban units (Fig. 1a).

\section{Water Sample analysis for physical and chemical properties}

The water samples were analyzed for $\mathrm{pH}$, Conductivity, Salinity, TDS, and Turbidity, using combined water analyzer (Systronics, Model-371, India). The quality assessment is based on the quantification of Potassium, Magnesium, and heavy metals using the Inductively Coupled Plasma Optical Emission Spectrometry (ICPSOES) (Thermo Scientific iCAP 7000 Series, India).

Total hardness was calculated using the expression total hardness= $4,1\left(\mathrm{Mg}^{2+}\right)+2,5\left(\mathrm{Ca}^{2+}\right)$, Sodium using Flame Photometric method. Calcium (EDTA Titrimetric Method), Chloride (Argentometric Method), Sulfates (IS: 3025 (Part-24)), Bicarbonates (Titration method), Nitrates (Chromotropic acid method) were analyzed by using standard protocols. 


\section{Data analysis}

\section{Water quality index (WQI)}

WQI was calculated by using Horton's method the expression given in Equation.

$\mathrm{WQI}=\Sigma \mathrm{q}_{\mathrm{n}} \mathrm{W}_{\mathrm{n}} / \Sigma \mathrm{W}_{\mathrm{n}}$

Where,

$\mathrm{q}_{\mathrm{n}}=$ Quality rating of $\mathrm{n}^{\text {th }}$ water quality parameter.

$\mathrm{W}_{\mathrm{n}}=$ Unit weight of $\mathrm{n}^{\text {th }}$ water quality parameter.

\section{Quality rating (qn)}

The quality rating (qn) is calculated using the expression given in Equation.

$\mathrm{q}_{\mathrm{n}}=\left[\left(\mathrm{V}_{\mathrm{n}}-\mathrm{V}_{\mathrm{id}}\right) /\left(\mathrm{S}_{\mathrm{n}}-\mathrm{V}_{\mathrm{id}}\right)\right] \times 100$

Where,

$\mathrm{Vn}=$ Estimated value of $\mathrm{n}^{\text {th }}$ water quality parameter at a given sample location.

$\mathrm{V}_{\mathrm{id}}=$ Ideal value for $\mathrm{n}^{\text {th }}$ parameter in pure water.

( $\mathrm{V}_{\mathrm{id}}$ for $\mathrm{pH}=7$ and 0 for all other parameters $)$

$S_{n}=$ Standard permissible value of $n^{\text {th }}$ water quality parameter.

\section{Unit weight (Wn) (Supplementary Table.1)}

The unit weight $(\mathrm{Wn})$ is calculated using the expression given in Equation.

$\mathrm{W}_{\mathrm{n}}=\mathrm{k} / \mathrm{S}_{\mathrm{n}}$

Where,
$S_{n}=$ Standard permissible value of $n^{\text {th }}$ water quality parameter.

$\mathrm{k}=$ Constant of proportionality, calculated by using the Equation.

$\mathrm{k}=\left[1 /\left(\Sigma 1 / \mathrm{S}_{\mathrm{n}=1,2, . \mathrm{n}}\right)\right]$

\section{Sodium absorption ratio (SAR)}

$\mathrm{SAR}=\mathrm{Na}^{+} /\left(\mathrm{Ca}^{2+}+\mathrm{Mg}^{2+} / 2\right)^{-1}$

Where all ionic concentrations are expressed in $\mathrm{meq} / \mathrm{L}$.

All the data analysis was carried out in Microsoft XL. 2013 and XL SAT. Software. Maps were created by using QGIS open software and Google earth. In addition to this the analytical values obtained for ground and surface samples are plotted on Piper (1994) trilinear diagram using Microsoft XL. 2013 to know the hydrochemical regime of the study area. In addition to this, US Salinity Laboratory hazard diagram was employed to classify and determine the suitability of ground and surface water for irrigation by correlating sodium absorption ratio/electrical conductivity.

\section{Results and Discussion}

The analytical results of water quality assessed in agroecosystems across the RUT are presented here.

The results are discussed in the light of various quality guidelines prescribed for specific water uses such as for drinking water (DW), irrigation water (IR) and for livestock consumption (LC)along the rural, urban and transition zones of Bengaluru. The results presented here are based on the data obtained for two consecutive years of 2017 and 2018 during the month of October. 


\section{Water quality index}

The water quality index of surface water in urban zone ranged from 5.85 to 255.65 in 2017 and 8.86 to 232.30 in 2018 and the mean water quality index of urban surface water was 78.56 which falls in C4 (Poor Irrigation and not fit for drinking) category, but it ranges from C1 (Excellent Drinking, Irrigation and Industrial) and C6 (Unfit for Drinking, Proper treatment required before use) category (Table 1). In transitional zone water quality ranged from 2.95-98.87 in 2017 and 5.56-91.10 in 2018, water quality falls in between C1 (Excellent Drinking, Irrigation and Industrial) and $\mathrm{C} 4$ (Poor Irrigation and not fit for drinking) but mean water quality of surface water of transition zone was 26.72 in 2017 and 33.80 in 2018 which falls in C2 (Good Domestic, Irrigation and Industrial) category.

Rural zone's water quality index of surface water ranges from 4.89 to 115.82 in 2017 and 6.40 to 102.41 in 2018 which shows that water quality index in rural surface water falls in between $\mathrm{C} 1$ (Excellent Drinking, Irrigation and Industrial) to C5 (Very Poor Restricted use for Irrigation) but the mean water quality was 46.35 in 2017 and 39.43 in 2018 which falls in C2 category. In urban area $80 \%$ percent of the water bodies analyzed WQI were unsuitable for drinking. The parameters selected for quantification of Water quality index and there classification was given in supplementary tables 1 and 3 respectively.

The above results indicate that the water quality is better as we move towards the rural zone from the urban zone among the RUT of Bengaluru. Similar studies conducted earlier (Ravikumar et al., 2013) in two water bodies in Bengaluru (Sankey tank and Mallathahalli lake)found that, Sankey tank water falls under good water class (50-100) while Mallathahalli lake water fall under poor water (100-200) category.

\section{Comparison of physicochemical properties of water}

One of the important water quality determining factors is the $\mathrm{pH}$ of water, which is a numerical expression of degree to which water is acidic or alkaline or the corrosive nature of water. Lower $\mathrm{pH}$ value tends to make water corrosive and higher $\mathrm{pH}$ leads to bad taste and has negative impact on skin and eyes (Rao and Rao 2010). pH value in the surface water along the RUT vary from 6.7 to 8.67 (2017) and 6.2 to 8.09 (2018) while in the surface water bodies in the urban, transition and rural zones it was slightly acidic to alkaline (table 2 and 3 ). Though the $\mathrm{pH}$ values did not exceed the standards prescribed for drinking, irrigation as well as for livestock use at present, there is every possibility that the values would reach the undesirable limits soon in surface water bodies (BSI, 2012).

Electrical conductivity of water is a function of total dissolved salts and is used as an indicator to represent the concentration of soluble salts in water (Purandara et al., 2003; Gupta et al., 2008) whose concentration beyond certain levels render water unfit for drinking, irrigation and livestock uses. The mean conductivity values recorded in surface water bodies in rural region were higher than in the urban and transition zones (Table 2 and 3 ), but within the permissible limits for drinking, irrigation and livestock use.

Classification of water bodies based on Electrical conductivity illustrates that the water ranges from low (C1) salinity to very high (C4) salinity (Fipps, 2003; Ravikumar $e t$ al., 2013) along the RUT zones of Bengaluru (Supplementary table 5). Similar trends were reported from earlier studies, and is attributed to high degree of anthropogenic interferences such as waste disposal, sewage inflow and agriculture runoff in the rural areas (Pandit, 2002). 
Total dissolved solids (TDS) that mainly consists of inorganic salts such as carbonates, bicarbonates, chlorides, sulphates, phosphates and nitrates of calcium, magnesium, sodium, potassium etc, and small amount of organic matter. The mean concentration of TDS for surface water in the agro-ecosystem along the RUT was in the range $472.90-296.63 \mathrm{mg} / \mathrm{L}$ (2017), 473 - $307.10 \mathrm{mg} / \mathrm{L}$ (2018). For surface water the maximum concentration of TDS was found in transition zones followed by rural and urban areas (Table 2 and 3). TDS concentration of surface water, for drinking water is in the desirable limit of BSI standards but the maximum concentration exceeded the desirable limits of BSI standards but within the acceptable limit $(2000 \mathrm{mg} / \mathrm{L})$. Though the TDS value does not cross the desirable limits for irrigation and livestock water in the RUT, results suggests that along the RUT it is in the alarming condition for surface water (BSI, 2012).

Turbidity is the measure of relative clarity of a liquid. Material that cause turbidity of water include clay, silt, finely divided inorganic and organic matter, algae, soluble colored organic compounds, and plankton and other microscopic organisms presence in the water. Rural surface water was more turbid (98 NTU (2017); 91.5 NTU (2018) than the transition (33 NTU (2017); 38 NTU (2018)) and urban (26 NTU (2017); 28 NTU (2018)) in the agroecosystems along RUT. The mean turbidity of urban surface exceeded the prescribed BSI standards for drinking water, while in case of transition and rural areas it was within the desirable limits. Highest turbidity of water was observed in surface water of rural area along RUT, which can be attributed to runoff from the agricultural lands (Table 2 and 3). Turbidity doesn't affect human health directly, but provides a congenial atmosphere for microbial growth which in turn cause diseases in human and animal upon consumption (Anon, 2019). The transition zone mean total hardness of surface water was highest in 2017 followed by rural and urban areas but in 2018 it was highest in rural area followed by transition and urban areas (Table 2 and 3). The total hardness of surface water for drinking purpose are within the acceptable limits, however maximum values crossed the desirable limits for both ground and surface water. The total hardness of water is due to the presence of polyvalent cat-ions (ions with a charge greater than +1 ). Presence of cat-ions in irrigation water helps in supplying secondary nutrients to the plants. Hardness mitigates metal toxicity in fish culture, because $\mathrm{Ca}^{2+}$ and $\mathrm{Mg}^{2+}$ help keep fish from absorbing metals such as lead, arsenic, and cadmium into their blood stream through their gills. The greater the hardness, the harder it is for toxic metals to be absorbed (Anon, 2019).

In the RUT ground and surface water ranged in between moderately hard to very hard range (McGowan, 2000; WHO, 2011).

Table.1 Water quality index in RUT zones of Bengaluru over two consecutive years

\begin{tabular}{|c|c|c|c|c|c|c|}
\hline \multicolumn{7}{|c|}{ Water Quality Index } \\
\hline Zones & Average & Max. & Min. & Average & Max. & Min. \\
\hline Urban & 78.56 & 255.65 & 5.85 & 84.20 & 232.30 & 8.86 \\
\hline Transition & 26.72 & 98.87 & 2.95 & 33.80 & 91.10 & 5.56 \\
\hline Rural & 46.35 & 115.82 & 4.89 & 39.43 & 102.41 & 6.40 \\
\hline
\end{tabular}


Table.2 Minimum, maximum, and mean values of physico-chemical parameters of surface water (U-urban, T-transition, R- rural)

\begin{tabular}{|c|c|c|c|c|c|c|c|c|c|c|c|c|c|c|}
\hline \multirow{3}{*}{$\begin{array}{l}\text { Sl. } \\
\text { no }\end{array}$} & \multirow[t]{3}{*}{ Category } & \multirow[t]{3}{*}{ Characteristics } & \multirow{2}{*}{\multicolumn{3}{|c|}{ Oct/17 }} & \multirow{2}{*}{\multicolumn{3}{|c|}{ Min. }} & \multirow{2}{*}{\multicolumn{3}{|c|}{$\begin{array}{l}\text { Mean } \\
\text { Oct/17 }\end{array}$}} & \multirow{3}{*}{$\begin{array}{c}\text { BSI (2012) } \\
\begin{array}{c}\text { Acceptable } \\
\text { limit }\end{array} \\
\text { DW }\end{array}$} & \multirow{2}{*}{\multicolumn{2}{|c|}{$\begin{array}{c}\text { Maximum } \\
\text { permissible } \\
\text { limits FAO, BSI, } \\
\text { Fipps }(2003)\end{array}$}} \\
\hline & & & & & & & & & & & & & & \\
\hline & & & $\mathbf{U}$ & $\mathbf{T}$ & $\mathbf{R}$ & $\mathbf{U}$ & $\mathbf{T}$ & $\mathbf{R}$ & $\mathbf{U}$ & $\mathbf{T}$ & $\mathbf{R}$ & & IW & $\mathbf{L W}$ \\
\hline \multirow[t]{6}{*}{1} & $\begin{array}{c}\text { General } \\
\text { parameters }\end{array}$ & $\mathrm{pH}$ & 7.97 & 7.78 & 8.67 & 6.93 & 6.7 & 6.58 & 7.55 & 7.43 & 7.50 & $6.5-8.5$ & $6.5-8.5$ & $6.5-8.5$ \\
\hline & & $\mathrm{EC}(\mu \mathrm{S} / \mathrm{L})$ & 1600 & 2210 & 2540 & 650 & 180 & 152 & 1028.10 & 1026.30 & 1300.50 & 2000 & $750-2000$ & 1500 \\
\hline & & Salinity $(\mathrm{mg} / \mathrm{L})$ & 450 & 570 & 580 & 160 & 40 & 30 & 305.60 & 140.00 & 166 & - & - & - \\
\hline & & $\mathrm{TH}(\mathrm{mg} / \mathrm{L})$ & 302.82 & 603.39 & 406.01 & 109.97 & 118.50 & 76.86 & 190.79 & 262.93 & 243.41 & $200-600$ & - & 300 \\
\hline & & TDS (mg/L) & 830 & 800 & 1140 & 222 & 72.3 & 44.90 & 472.90 & 296.63 & 330.46 & $500-1000$ & $450-2000$ & 3000 \\
\hline & & Turbidity (NTU) & 26 & 33 & 98 & 5.6 & 0.8 & 2 & 16.66 & 8.01 & 32.02 & 1 & - & - \\
\hline \multirow[t]{4}{*}{2} & $\begin{array}{l}\text { Major } \\
\text { cations }\end{array}$ & $\mathrm{K}(\mathrm{mg} / \mathrm{L})$ & 32.28 & 12.53 & 20.81 & 1.30 & 2.80 & 0.76 & 14.65 & 6.18 & 8.87 & 10 & - & - \\
\hline & & $\mathrm{Na}(\mathrm{mg} / \mathrm{L})$ & 145.30 & 97.20 & 33.80 & 31.40 & 18.30 & 18.30 & 76.08 & 43.75 & 25.57 & 100 & 69 & - \\
\hline & & $\mathrm{Mg}(\mathrm{mg} / \mathrm{L})$ & 28.21 & 8.84 & 82.39 & 7.25 & 2.46 & 2.13 & 18.82 & 5.60 & 16.09 & 30 & - & 250 \\
\hline & & $\mathrm{Ca}(\mathrm{mg} / \mathrm{L})$ & 98.30 & 162.3 & 152.30 & 22.30 & 32.9 & 23.30 & 45.45 & 85.02 & 70.97 & 75 & - & 500 \\
\hline \multirow[t]{4}{*}{3} & $\begin{array}{l}\text { Major } \\
\text { anions }\end{array}$ & $\mathrm{NO}_{3}(\mathrm{mg} / \mathrm{L})$ & 62.30 & 45 & 52.30 & 1.25 & 12.3 & 13.20 & 24.96 & 21.67 & 31.70 & 45 & - & 100 \\
\hline & & $\mathrm{Cl}(\mathrm{mg} / \mathrm{L})$ & 256.54 & 235.25 & 245.20 & 125.30 & 78.90 & 98.90 & 196.25 & 128.94 & 151.80 & 250 & 141.6 & - \\
\hline & & $\mathrm{SO}_{4}(\mathrm{mg} / \mathrm{L})$ & 75.90 & 85.60 & 63.30 & 21.30 & 18.90 & 25.10 & 46.87 & 46.39 & 38.01 & 200 & - & 500 \\
\hline & & $\mathrm{HCO}_{3}(\mathrm{mg} / \mathrm{L})$ & 231.65 & 231.65 & 231.65 & 37.20 & 89.64 & 47.60 & 123.75 & 134.36 & 111.86 & 200 & - & 500 \\
\hline \multirow[t]{12}{*}{4} & $\begin{array}{l}\text { Heavy } \\
\text { Metals }\end{array}$ & $\mathrm{Al}(\mathrm{mg} / \mathrm{L})$ & 5.4 & 5.43 & 2.65 & 2.01 & 0.29 & 0.044 & 0.741 & 0.876 & 0.3944 & 0.03 & 5.0 & 5.0 \\
\hline & & As (mg/L) & 0.012 & 0.011 & 0.012 & 0.001 & 0.001 & 0.001 & 0.0059 & 0.0025 & 0.005 & 0.01 & 0.10 & 0.2 \\
\hline & & $\mathrm{Ag}(\mathrm{mg} / \mathrm{L})$ & 0.03 & 0.011 & 0.012 & 0.002 & 0.001 & 0.002 & 0.008 & 0.0036 & 0.0042 & 0.1 & NA & NA \\
\hline & & B (mg/L) & 0.111 & 0.001 & 0.029 & 0.001 & 0 & 0.024 & 0.0112 & 0.0001 & 0.0053 & 0.5 & 0.7 & 5.0 \\
\hline & & $\mathrm{Fe}(\mathrm{mg} / \mathrm{L})$ & 1.75 & 0.49 & 6.542 & 0.038 & 0.015 & 0.012 & 0.8701 & 0.1351 & 1.2934 & 0.3 & 5.0 & NA \\
\hline & & Co $(\mathrm{mg} / \mathrm{L})$ & 0 & 0 & 0.002 & 0 & 0 & 0 & 0 & 0 & 0.0002 & - & 0.05 & 1.0 \\
\hline & & $\mathrm{Ni}(\mathrm{mg} / \mathrm{L})$ & 0.18 & 0.014 & 0.033 & 0.001 & 0.001 & 0.001 & 0.0226 & 0.0029 & 0.005 & 0.02 & 0.2 & NA \\
\hline & & $\mathrm{Zn}(\mathrm{mg} / \mathrm{L})$ & 0.036 & 0.045 & 0.215 & 0.001 & 0.002 & 0.002 & 0.0054 & 0.0084 & 0.0287 & 5 & 2.0 & 24 \\
\hline & & $\mathrm{Cr}(\mathrm{mg} / \mathrm{L})$ & 0.01 & 0.02 & 0.04 & 0.003 & 0.002 & 0.019 & 0.001 & 0.0022 & 0.0065 & 0.05 & 0.1 & 1.0 \\
\hline & & $\mathrm{Pb}(\mathrm{mg} / \mathrm{L})$ & 0.053 & 0.03 & 0.018 & 0.001 & 0.002 & 0.004 & 0.011 & 0.0045 & 0.0057 & 0.01 & 5.0 & 0.1 \\
\hline & & $\mathrm{Mn}(\mathrm{mg} / \mathrm{L})$ & 1.886 & 0.098 & 0.418 & 0.003 & 0.001 & 0.002 & 0.4136 & 0.0278 & 0.0858 & 0.1 & NA & 0.05 \\
\hline & & $\mathrm{Cu}(\mathrm{mg} / \mathrm{L})$ & 0.152 & 0.012 & 0.004 & 0.004 & 0.001 & 0.002 & 0.0208 & 0.0042 & 0.0016 & 0.05 & 0.2 & 0.5 \\
\hline
\end{tabular}


Table.3 Minimum, maximum, and mean values of physico-chemical parameters of surface water (U-urban, T-transition, R- rural)

\begin{tabular}{|c|c|c|c|c|c|c|c|c|c|c|c|c|c|c|}
\hline \multirow[t]{2}{*}{$\begin{array}{l}\text { Sl. } \\
\text { no }\end{array}$} & \multirow[t]{2}{*}{$\begin{array}{c}\text { Categor } \\
\mathbf{y}\end{array}$} & \multirow[t]{2}{*}{$\begin{array}{c}\text { Characteristic } \\
\text { s }\end{array}$} & \multicolumn{3}{|c|}{ Oct $/ 18$} & \multicolumn{3}{|c|}{ Oct $/ 18$} & \multicolumn{3}{|c|}{ Mean } & \multirow{2}{*}{$\begin{array}{c}\text { BSI (2012) } \\
\begin{array}{c}\text { Acceptable } \\
\text { limit }\end{array} \\
\text { DW } \\
\end{array}$} & \multicolumn{2}{|c|}{$\begin{array}{c}\text { Maximum } \\
\text { permissible } \\
\text { limits FAO, BSI, } \\
\text { Fipps }(2003)\end{array}$} \\
\hline & & & $\mathbf{U}$ & $\mathbf{T}$ & $\mathbf{R}$ & $\mathbf{U}$ & $\mathbf{T}$ & $\mathbf{R}$ & $\mathbf{U}$ & $\mathbf{T}$ & $\mathbf{R}$ & & IW & $\mathbf{L W}$ \\
\hline \multirow[t]{6}{*}{1} & $\begin{array}{c}\text { General } \\
\text { paramete } \\
\text { rs }\end{array}$ & $\mathrm{pH}$ & 7.97 & 7.78 & 8.09 & 6.31 & 6.2 & 6.32 & 7.45 & 7.27 & 7.49 & $6.5-8.5$ & $6.5-8.5$ & $6.5-8.5$ \\
\hline & & $\mathrm{EC}(\mu \mathrm{S} / \mathrm{L})$ & 1625 & 2220 & 2648 & 245 & 181 & 157 & 987.80 & 1038 & 1316.90 & 2000 & $\begin{array}{l}750- \\
2000\end{array}$ & 1500 \\
\hline & & Salinity $(\mathrm{mg} / \mathrm{L})$ & 581 & 576 & 581 & 245 & 45 & 31 & 370.60 & 147.50 & 169.50 & - & - & - \\
\hline & & TH (mg/L) & 300.70 & 415.53 & 399.62 & 108.55 & 120.30 & 73.00 & 190.10 & 231.67 & 241.50 & $200-600$ & - & 300 \\
\hline & & TDS (mg/L) & 835 & 801 & 1140 & 121 & 78 & 45 & 473 & 307.10 & 331.54 & $500-1000$ & $\begin{array}{l}450- \\
2000\end{array}$ & 3000 \\
\hline & & $\begin{array}{l}\text { Turbidity } \\
\text { (NTU) }\end{array}$ & 17 & 38 & 98 & 0.56 & 2.5 & 2 & 3.03 & 11.61 & 32.33 & 1 & - & - \\
\hline \multirow[t]{4}{*}{2} & $\begin{array}{l}\text { Major } \\
\text { cations }\end{array}$ & $\mathrm{K}(\mathrm{mg} / \mathrm{L})$ & 33.46 & 14.58 & 21.32 & 2.30 & 1.81 & 1.66 & 15.27 & 6.31 & 8.61 & 10 & - & - \\
\hline & & $\mathrm{Na}(\mathrm{mg} / \mathrm{L})$ & 144.30 & 96.09 & 33.72 & 31.45 & 20.15 & 18.30 & 76.12 & 41.70 & 25.53 & 100 & 69 & - \\
\hline & & $\mathrm{Mg}(\mathrm{mg} / \mathrm{L})$ & 27.56 & 9.13 & 82.65 & 8.57 & 1.70 & 1.13 & 19.02 & 5.34 & 15.90 & 30 & - & 250 \\
\hline & & $\mathrm{Ca}(\mathrm{mg} / \mathrm{L})$ & 97.32 & 162.30 & 151.32 & 23.34 & 33.62 & 23.30 & 44.86 & 83.91 & 70.53 & 75 & - & 500 \\
\hline \multirow[t]{4}{*}{3} & $\begin{array}{l}\text { Major } \\
\text { anions }\end{array}$ & $\mathrm{NO}_{3}(\mathrm{mg} / \mathrm{L})$ & 62.30 & 47.32 & 52.34 & 2.24 & 12.3 & 14.52 & 26.05 & 23.00 & 31.82 & 45 & - & 100 \\
\hline & & $\mathrm{Cl}(\mathrm{mg} / \mathrm{L})$ & 256.54 & 165.32 & 245.31 & 125.31 & 78.90 & 98.99 & 194.96 & 120.79 & 150.14 & 250 & 141.6 & - \\
\hline & & $\mathrm{SO}_{4}(\mathrm{mg} / \mathrm{L})$ & 75.90 & 85.60 & 63.30 & 21.30 & 18.90 & 25.10 & 46.87 & 46.39 & 38.01 & 200 & - & 500 \\
\hline & & $\mathrm{HCO}_{3}(\mathrm{mg} / \mathrm{L})$ & 182.31 & 231.65 & 168.34 & 56.30 & 47.32 & 34.62 & 118.16 & 131.39 & 98.29 & 200 & - & 500 \\
\hline \multirow[t]{12}{*}{4} & $\begin{array}{l}\text { Heavy } \\
\text { Metals }\end{array}$ & $\mathrm{Al}(\mathrm{mg} / \mathrm{L})$ & 4.23 & 5.96 & 3.21 & 1.75 & 0.89 & 0.12 & 0.598 & 1.109 & 0.612 & 0.03 & 5.0 & 5.0 \\
\hline & & As (mg/L) & 0.01 & 0.021 & 0.032 & 0.002 & 0.002 & 0.001 & 0.0056 & 0.0057 & 0.0077 & 0.01 & 0.10 & 0.2 \\
\hline & & $\mathrm{Ag}(\mathrm{mg} / \mathrm{L})$ & 0.071 & 0.072 & 0.009 & 0.001 & 0.002 & 0.002 & 0.0224 & 0.028 & 0.0034 & 0.1 & NA & NA \\
\hline & & B (mg/L) & 0.111 & 0.001 & 0.032 & 0 & 0.001 & 0.001 & 0.0111 & 0.0001 & 0.0056 & 0.5 & 0.7 & 5.0 \\
\hline & & $\mathrm{Fe}(\mathrm{mg} / \mathrm{L})$ & 1.69 & 0.49 & 1.25 & 0.001 & 0.019 & 0.013 & 0.643 & 0.1536 & 0.4472 & 0.3 & 5.0 & NA \\
\hline & & $\mathrm{Co}(\mathrm{mg} / \mathrm{L})$ & 0 & 0 & 0.003 & 0 & 0 & 0 & 0 & 0 & 0.0003 & - & 0.05 & 1.0 \\
\hline & & $\mathrm{Ni}(\mathrm{mg} / \mathrm{L})$ & 0.18 & 0.032 & 0.033 & 0.001 & 0.004 & 0.002 & 0.0236 & 0.0036 & 0.0059 & 0.02 & 0.2 & NA \\
\hline & & $\mathrm{Zn}(\mathrm{mg} / \mathrm{L})$ & 0.046 & 0.123 & 0.215 & 0.003 & 0.003 & 0.001 & 0.0084 & 0.0187 & 0.0292 & 5 & 2.0 & 24 \\
\hline & & $\mathrm{Cr}(\mathrm{mg} / \mathrm{L})$ & 0.02 & 0.03 & 0.04 & 0.001 & 0.002 & 0.001 & 0.0022 & 0.0033 & 0.0051 & 0.05 & 0.1 & 1.0 \\
\hline & & $\mathrm{Pb}(\mathrm{mg} / \mathrm{L})$ & 0.005 & 0.006 & 0.006 & 0.001 & 0.001 & 0.001 & 0.0018 & 0.0023 & 0.0022 & 0.01 & 5.0 & 0.1 \\
\hline & & $\operatorname{Mn}(m g / L)$ & 1.886 & 0.452 & 0.063 & 0.025 & 0.016 & 0.002 & 0.3528 & 0.0764 & 0.03 & 0.1 & NA & 0.05 \\
\hline & & $\mathrm{Cu}(\mathrm{mg} / \mathrm{L})$ & 0.051 & 0.09 & 0.051 & 0.001 & 0.001 & 0.002 & 0.01283 & 0.0236 & 0.0141 & 0.05 & 0.2 & 0.5 \\
\hline
\end{tabular}


Fig.1 Map of the North and South transects of Bengaluru where study was conducted

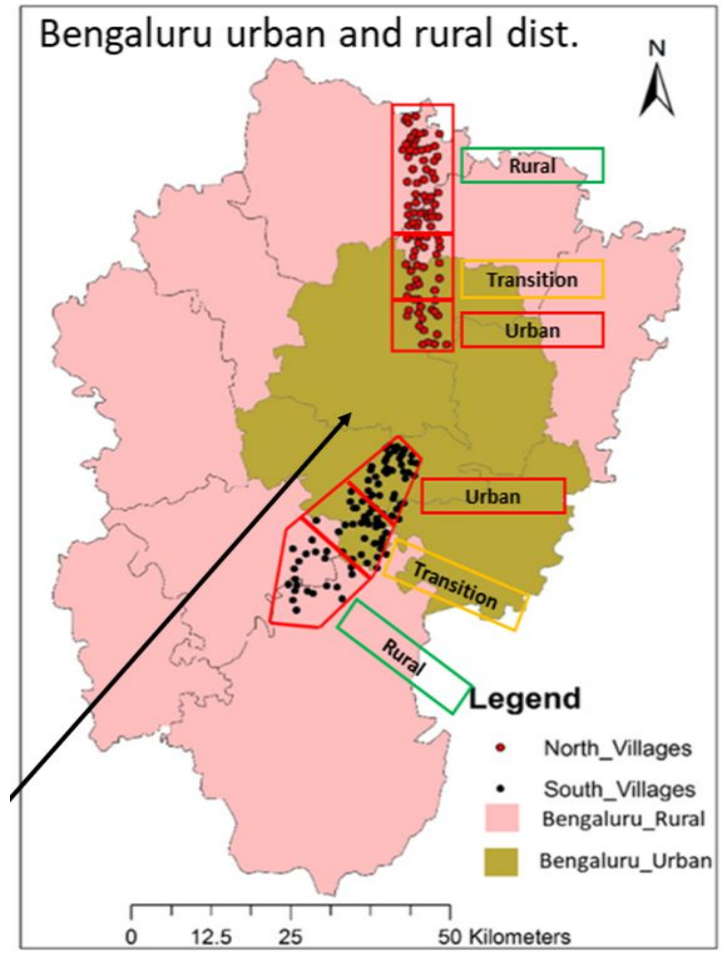

Fig.1a Map showing the location of representative sample sites from where ground and surface water samples were drawn with in the $1 \mathrm{~km}$ radius of agricultural lands in urban zone of north transect

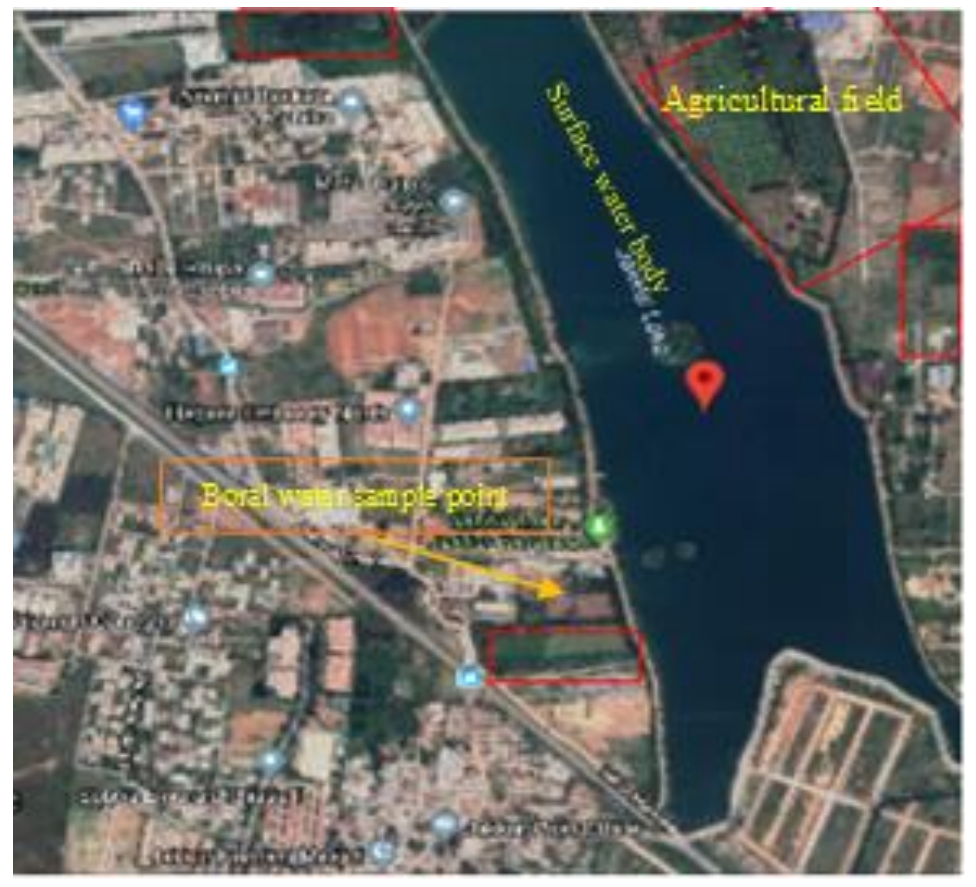


Table.4 The k-value and unit weight of each of the physicochemical parameters used for WQI determination

\begin{tabular}{|c|c|c|c|}
\hline Parameters & $\mathbf{S}_{\mathbf{n}}$ & k-value & $W_{n}$ \\
\hline As & 0.01 & 0.003166 & 0.316606 \\
\hline Ag & 0.1 & 0.003166 & 0.031661 \\
\hline B & 0.5 & 0.003166 & 0.006332 \\
\hline $\mathbf{F e}$ & 0.3 & 0.003166 & 0.010554 \\
\hline $\mathbf{N i}$ & 0.02 & 0.003166 & 0.158303 \\
\hline $\mathbf{Z n}$ & 5 & 0.003166 & 0.000633 \\
\hline $\mathrm{Cr}$ & 0.05 & 0.003166 & 0.063321 \\
\hline $\mathbf{P b}$ & 0.01 & 0.003166 & 0.316606 \\
\hline Mn & 0.1 & 0.003166 & 0.031661 \\
\hline $\mathbf{K}$ & 10 & 0.003166 & 0.000317 \\
\hline $\mathrm{Cu}$ & 0.05 & 0.003166 & 0.063321 \\
\hline $\mathbf{N a}$ & 100 & 0.003166 & 0.000032 \\
\hline Mg & 30 & 0.003166 & 0.000106 \\
\hline $\mathbf{C a}$ & 75 & 0.003166 & 0.000042 \\
\hline No3 & 45 & 0.003166 & 0.000070 \\
\hline Cl & 250 & 0.003166 & 0.000013 \\
\hline Sulphate & 200 & 0.003166 & 0.000016 \\
\hline $\mathbf{P h}$ & 8.5 & 0.003166 & 0.000372 \\
\hline TDS & 500 & 0.003166 & 0.000006 \\
\hline EC & 2000 & 0.003166 & 0.0000016 \\
\hline total hardness & 300 & 0.003166 & 0.000011 \\
\hline & & \multicolumn{2}{|c|}{$\Sigma W n=1.000$} \\
\hline
\end{tabular}

Fig.2 Piper diagram surface water samples of 2017

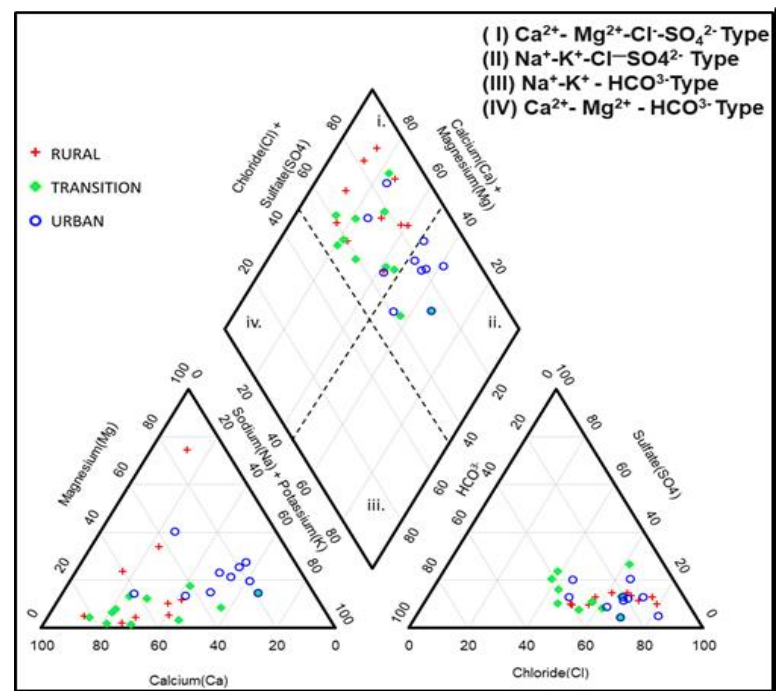


Table.5 Surface water points

\begin{tabular}{|c|c|c|c|}
\hline Transect zones & Water body name & Latitudes & Longitudes \\
\hline South urban & Avalahalli lake & $12^{0} 51^{\prime} 55.3 " \mathrm{~N}$ & $77^{0} 34^{\prime} 00.0^{\prime \prime} \mathrm{E}$ \\
\hline South urban & Krishna nagarkere & $12^{0} 52^{\prime} 25.0^{\prime \prime} \mathrm{N}$ & $77^{0} 34^{\prime} 46.2^{\prime \prime} \mathrm{E}$ \\
\hline South urban & Gattigere lake & $12^{0} 51^{\prime} 10.3^{\prime \prime} \mathrm{N}$ & $77^{0} 35^{\prime} 25.7^{\prime \prime} \mathrm{E}$ \\
\hline South urban & Chikkammannahalli pond & $12^{0} 50^{\prime} 56.6^{\prime \prime} \mathrm{N}$ & $77^{0} 36^{\prime} 13.0^{\prime \prime} \mathrm{E}$ \\
\hline South urban & Chunchugatta lake & $12^{0} 53^{\prime} 15.0^{\prime \prime} \mathrm{N}$ & $77^{0} 34^{\prime} 30.6^{\prime \prime} \mathrm{E}$ \\
\hline South transition & Tharalu pond & $12^{0} 47^{\prime} 15.6^{\prime \prime} \mathrm{N}$ & $77^{0} 31^{\prime} 24.7^{\prime \prime} \mathrm{E}$ \\
\hline South transition & Mariapura lake & $12^{0} 46^{\prime} 29.7^{\prime \prime} \mathrm{N}$ & $77^{0} 32^{\prime} 13.6^{\prime \prime} \mathrm{E}$ \\
\hline South transition & Kaggalipura lake & $12^{0} 47^{\prime} 50.4 " \mathrm{~N}$ & $77^{0} 30^{\prime} 21.8^{\prime \prime} \mathrm{E}$ \\
\hline South transition & Gulakamale lake & $12^{0} 48^{\prime} 23.9^{\prime \prime} \mathrm{N}$ & $77^{0} 31^{\prime} 40.9^{\prime \prime} \mathrm{E}$ \\
\hline South transition & Kuppareddykere & $12^{0} 50^{\prime} 28.4^{\prime \prime} \mathrm{N}$ & $77^{0} 31^{\prime} 05.4^{\prime \prime} \mathrm{E}$ \\
\hline South rural & Gabbadikere & $12^{0} 42^{\prime} 34.7^{\prime \prime} \mathrm{N}$ & $77^{0} 29^{\prime} 00.3^{\prime \prime} \mathrm{E}$ \\
\hline South rural & Kaggalahallikere & $12^{0} 43^{\prime} 49.6^{\prime \prime} \mathrm{N}$ & $77^{0} 29^{\prime} 20.3^{\prime \prime} \mathrm{E}$ \\
\hline South rural & KG Gollarapalaya & $12^{0} 44^{\prime} 42.0^{\prime \prime} \mathrm{N}$ & $77^{0} 28^{\prime} 03.8^{\prime \prime} \mathrm{E}$ \\
\hline South rural & Bhramangala lake & $12^{0} 45^{\prime} 40.9^{\prime \prime} \mathrm{N}$ & $77^{0} 25^{\prime} 26.4^{\prime \prime} \mathrm{E}$ \\
\hline South rural & Nelaguli lake & $12^{0} 46^{\prime} 41.5^{\prime \prime} \mathrm{N}$ & $77^{0} 29^{\prime} 33.9^{\prime \prime} \mathrm{E}$ \\
\hline North urban & Jakkur lake & $13^{\circ} 05^{\prime} 08.8^{\prime \prime} \mathrm{N}$ & 77³6'39.1"E \\
\hline North urban & Palanahalli lake & $13^{\circ} 06^{\prime} 56.7^{\prime \prime} \mathrm{N}$ & 77³6'59.4"E \\
\hline North urban & Allalasandra lake & $13^{\circ} 05^{\prime} 26.7^{\prime \prime} \mathrm{N}$ & $77^{\circ} 35^{\prime} 13.4^{\prime \prime E}$ \\
\hline North urban & Amrutahalli lake & $13^{\circ} 03^{\prime} 41.5^{\prime \prime} \mathrm{N}$ & $77^{\circ} 35^{\prime} 55.5^{\prime \prime} \mathrm{E}$ \\
\hline North urban & Yelahankakere & $13^{\circ} 06^{\prime} 47.1^{\prime \prime} \mathrm{N}$ & 77³5'33.7"E \\
\hline North transition & Kamenahalli & $13^{\circ} 12^{\prime} 31.0^{\prime \prime} \mathrm{N}$ & $77^{\circ} 35^{\prime} 32.1^{\prime \prime} \mathrm{E}$ \\
\hline North transition & Suradhenupura & $13^{\circ} 13^{\prime} 09.1^{\prime \prime} \mathrm{N}$ & 77³3'20.1"E \\
\hline North transition & Nagadasanahalli & $13^{\circ} 09^{\prime} 21.1^{\prime \prime} \mathrm{N}$ & $77^{\circ} 34^{\prime} 21.8^{\prime \prime} \mathrm{E}$ \\
\hline North transition & Gantiganahalli & $13^{\circ} 08^{\prime} 32.2^{\prime \prime} \mathrm{N}$ & $77^{\circ} 35^{\prime} 25.2^{\prime \prime} \mathrm{E}$ \\
\hline North transition & Gantiganahalli lake & $13^{\circ} 08^{\prime} 17.5^{\prime \prime} \mathrm{N}$ & 77³4'38.6"E \\
\hline North rural & K.G Govindapura, & $13^{\circ} 16^{\prime} 58.3^{\prime \prime} \mathrm{N}$ & $77^{\circ} 33^{\prime} 08.9^{\prime \prime} \mathrm{E}$ \\
\hline North rural & DoddaballapuraKere & $13^{\circ} 19^{\prime} 28.2^{\prime \prime} \mathrm{N}$ & $77^{\circ} 32^{\prime} 10.2^{\prime \prime} \mathrm{E}$ \\
\hline North rural & Marahalli & $13^{\circ} 21^{\prime} 38.8^{\prime \prime} \mathrm{N}$ & $77^{\circ} 35^{\prime} 56.8^{\prime \prime} \mathrm{E}$ \\
\hline North rural & ShivapuraKere & $13^{\circ} 18^{\prime} 58.2^{\prime \prime N}$ & $77^{\circ} 34^{\prime} 06.8^{\prime \prime} \mathrm{E}$ \\
\hline North rural & Kollurkere & $13^{\circ} 20^{\prime} 45.6^{\prime \prime} \mathrm{N}$ & $77^{\circ} 30^{\prime} 52.0 " \mathrm{E}$ \\
\hline
\end{tabular}


Table.6 Water quality classification based on water quality index

\begin{tabular}{|c|c|c|}
\hline Category of water & Range of water quality & Uses \\
\hline C1 & $0-25$ & $\begin{array}{c}\text { Excellent Drinking, } \\
\text { Irrigation and Industrial }\end{array}$ \\
\hline C2 & $25-50$ & $\begin{array}{c}\text { Good Domestic, Irrigation } \\
\text { and Industrial }\end{array}$ \\
\hline C3 & $51-75$ & Fair Irrigation and Industrial \\
\hline C4 & $76-100$ & Poor Irrigation \\
\hline C5 & $101-150$ & $\begin{array}{c}\text { Very Poor Restricted use for } \\
\text { Irrigation }\end{array}$ \\
\hline C6 & Above 150 Unfit for Drinking Proper treatment required \\
before use.
\end{tabular}

Table.7 Classification of irrigation water based on electrical conductivity (Ravikumar, 2013)

\begin{tabular}{|c|c|c|}
\hline $\mathbf{1}$ & Type of water & Suitability for irrigation \\
\hline $\mathbf{2}$ & $\begin{array}{c}\text { Low salinity water }(\mathrm{C} 1) \text { conductivity } \\
\text { between } 100 \text { and } 250 \mu \mathrm{S} / \mathrm{cm}\end{array}$ & $\begin{array}{c}\text { Suitable for all types of crops and all kinds of } \\
\text { soil.Permissible under normal irrigation practices } \\
\text { exceptin soils of extremely low permeability }\end{array}$ \\
\hline $\mathbf{3}$ & $\begin{array}{c}\text { Medium salinity water }(\mathrm{C} 2) \text { conductivity } \\
\text { between } 250 \text { and } 750 \mu \mathrm{S} / \mathrm{cm}\end{array}$ & $\begin{array}{c}\text { Can be used, if a moderate amount of leaching } \\
\text { occurs.Normal salt tolerant plants can be grown } \\
\text { withoutmuch salinity control }\end{array}$ \\
\hline $\mathbf{4}$ & $\begin{array}{c}\text { Very high salinity water }(\mathrm{C} 3) \text { conductivity }(\mathrm{C} 4) \text { conductivity more than } \\
\text { between } 750 \text { and } 2,250 \mu \mathrm{S} / \mathrm{cm}\end{array}$ & $\begin{array}{c}\text { Unsuitable for soil with restricted drainage. Only } \\
\text { highsalttolerant plants can be grown }\end{array}$ \\
\hline
\end{tabular}

Table.8 Classification of salinity hazard based on the electric conductivity given by USSL, 1954

\begin{tabular}{|c|c|c|}
\hline Categories & Salinity hazard & Interpretation \\
\hline $\mathbf{C}_{\mathbf{1}}$ & Low-salinity water & $\begin{array}{c}\text { Used for irrigation with most crops on most soils with little likelihood } \\
\text { that soil salinity will develop. Some leaching is required, but this occurs } \\
\text { under normal irrigation practices except in soils of extremely low } \\
\text { permeability. }\end{array}$ \\
\hline $\mathbf{C}_{\mathbf{2}}$ & $\begin{array}{c}\text { Medium-salinity } \\
\text { water }\end{array}$ & $\begin{array}{c}\text { Used if a moderate amount of leaching occurs. Plants with moderate } \\
\text { salt- tolerance can be grown in most cases without special practices for } \\
\text { salinity control. }\end{array}$ \\
\hline $\mathbf{C}_{\mathbf{3}}$ & High-salinity water & $\begin{array}{c}\text { Used on soils with restricted drainage. Even with adequate drainage, } \\
\text { special management for salinity control may be required and plants with } \\
\text { good salt tolerance should be selected. }\end{array}$ \\
\hline $\mathbf{C}_{\mathbf{4}}$ & $\begin{array}{c}\text { Very high salinity } \\
\text { water }\end{array}$ & $\begin{array}{c}\text { Not suitable for irrigation under ordinary conditions, but may be used } \\
\text { occasionally under very special circumstances. The soils must be } \\
\text { permeable, drainage must be adequate, irrigation water must be applied } \\
\text { in excess to provide considerable leaching and very salt-tolerant crops } \\
\text { should be selected. }\end{array}$ \\
\hline
\end{tabular}


Table.9 Classification of sodium hazard based on the electric conductivity given by USSL, 1954

\begin{tabular}{|c|c|c|}
\hline Categories & Sodium hazard & Interpretation \\
\hline $\mathrm{S}_{1}$ & $\begin{array}{l}\text { Low-sodium } \\
\text { water }\end{array}$ & $\begin{array}{l}\text { Used for irrigation on almost all soils with little danger of the } \\
\text { development of harmful levels of exchangeable sodium. However } \\
\text { sodium-sensitive crops such as stone fruit trees and avocados may } \\
\text { accumulate injurious concentrations of sodium }\end{array}$ \\
\hline $\mathbf{S}_{2}$ & $\begin{array}{l}\text { Medium-sodium } \\
\text { water }\end{array}$ & $\begin{array}{l}\text { Certain fine-textured soils having high cation-exchange capacity } \\
\text { under low leaching conditions, unless gypsum is present in the } \\
\text { soil. This water may be used on coarse-textured or organic soils } \\
\text { with good permeability. }\end{array}$ \\
\hline $\mathbf{S}_{\mathbf{3}}$ & $\begin{array}{l}\text { High-sodium } \\
\text { water }\end{array}$ & $\begin{array}{l}\text { Produce harmful levels of exchangeable sodium in most soils and } \\
\text { will require special soil management }\end{array}$ \\
\hline $\mathbf{S}_{4}$ & $\begin{array}{l}\text { Very high sodium } \\
\text { water }\end{array}$ & $\begin{array}{l}\text { Generally unsatisfactory for irrigation unless special action is } \\
\text { taken, such as addition of gypsum to soil (Lyerly and } \\
\text { Longenecker, 1957). Whereas USSL diagram classify irrigation } \\
\text { water based on EC and SAR. }\end{array}$ \\
\hline
\end{tabular}

Fig.3 Piper diagram surface water samples of 2018

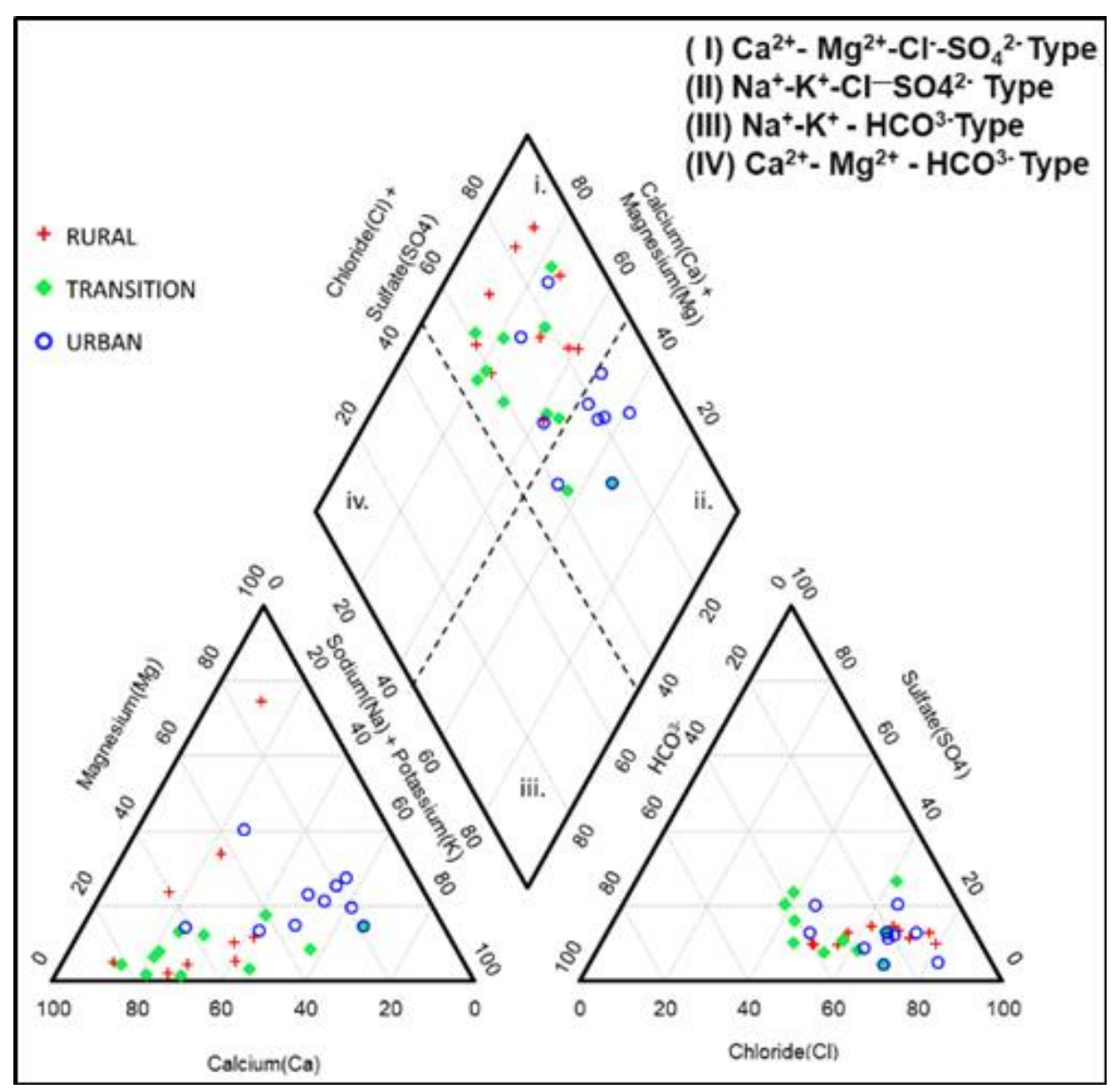


Fig.4 USSLH diagram for surface water samples

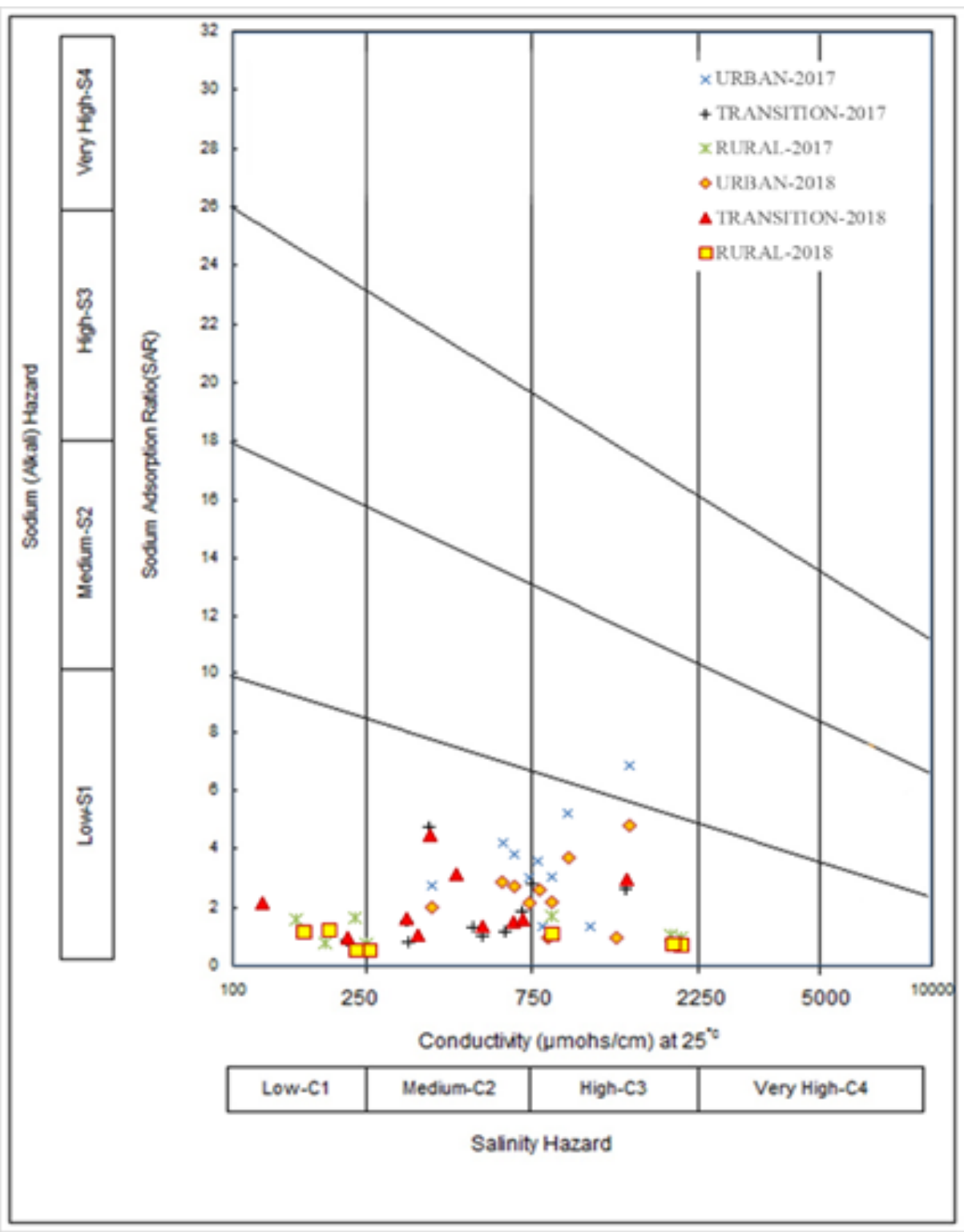

The an-ion and cat-ion mean concentration for the urban and rural zone in surface water trend was in the order of $\mathrm{Cl}>\mathrm{HCO}_{3}>\mathrm{SO}_{4}>\mathrm{NO}_{3}$ and $\mathrm{Ca}>\mathrm{Na}>\mathrm{K}>\mathrm{Mg}$ respectively, but in transitional zone an-ion and cat-ion trend was in the order of $\mathrm{HCO}_{3}>\mathrm{Cl}>\mathrm{SO}_{4}>\mathrm{NO}_{3}$ and $\mathrm{Ca}>\mathrm{Na}>\mathrm{K}>\mathrm{Mg}$ respectively (Table 2 and 3 ). The $\mathrm{K}, \mathrm{Na}, \mathrm{Ca}$, $\mathrm{NO}_{3}$ and $\mathrm{Cl}$ maximum concentrations of surface water exceeded the desirable limits for drinking water in urban zone, while $\mathrm{Na}$ was found to exceed the acceptable limits for irrigation purpose in urban zone. In the transition and rural zones $\mathrm{Ca}, \mathrm{K}$, and $\mathrm{NO}_{3}$ maximum concentration crossed the desirable limits for drinking purpose, but $\mathrm{Cl}$ was found to be higher than the prescribed levels for irrigation. However the an-ion and cat-ion mean concentration of surface water were found within the permissible limits for all selected end uses (Table 2 and 3).

The heavy metals concentrations in the surface water of agro-ecosystems along the RUT were tabulated in Table 2 and 3. Aluminum (Al) 
concentration in surface water along the RUT ranged between 5.4-0.29 $\mathrm{mg} / \mathrm{Lin}$ 2017, however in $2018 \mathrm{Al}$ concentration in surface water ranged between $5.96-0.12 \mathrm{mg} / \mathrm{L}$. The mean $\mathrm{Al}$ concentration was found maximum in surface water of transition zone followed by rural and urban regions during 2017 and 2018, but during 2017 in surface water it was more in urban than rural zones (Table 2 and 3).The concentration of aluminum crossed the acceptable limits of BSI for drinking, irrigation and livestock uses.

Heavy metals like silver, boron, iron, nickel, lead, manganese and copper, mean concentrations were found highest in urban surface water and in transition zone only copper was found highest and in rural zone arsenic, zinc, and chromium were found highest during 2017. But in 2018 heavy metals like boron, iron, nickel, manganese mean concentration was detected with highest concentration in urban surface water, in transition zone, copper was highest and in rural areas arsenic, silver, cobalt, zinc, chromium and lead were found highest (Table 2 and 3). Though heavy metal concentrations are within the prescribed standards for all said end uses at present, results suggests that along the RUT they are increasing at alarming rates for all selected end uses of surface water. It is important to note that very small concentration of heavy metals are capable of producing adverse health effect on human, plants and other organisms.

\section{Hydrochemical facies}

The surface water was subject to an analysis based on the Cation and anion concentration using the piper diagram approach (Fig. 2 and $3)$. From this approach it is found that strong alkalies $\left(\mathrm{Ca}^{2+}\right.$ and $\left.\mathrm{Mg}^{2+}\right)$ significantly exceed the weak alkilies $\left(\mathrm{Na}^{+}\right.$and $\mathrm{K}^{+}$), and strong acids $\left(\mathrm{Cl}^{-}\right.$and $\left.\mathrm{SO}_{4}{ }^{2-}\right)$ significantly exceed the weak acids $\left(\mathrm{HCO}_{3}^{-}\right.$and $\left.\mathrm{CO}_{3}{ }^{2-}\right)$ in surface water of agroecosystems along the RUT of Bengaluru. Most of the surface water samples were of mixed $\mathrm{Ca}-\mathrm{Mg}-\mathrm{Cl}$ type followed by $\mathrm{Ca}-\mathrm{Mg}-\mathrm{Cl}-\mathrm{SO}_{4}$ type and $\mathrm{Na}-\mathrm{K}-\mathrm{Cl}-\mathrm{SO}_{4}$ type along the RUT of Bengaluru (Fig. 2 and 3). From this analysis it is possible to know the relative abundance of common ions in water samples which helps to understand the future effect on soil health, Bioaccumulation of ions in the food chain (ex. Bioaccumulation of chlorine) and negative and positive effects on crops in the agroecosystems. For example micro nutrients like $\mathrm{Ca}, \mathrm{Mg}$ will be supplied to the plant root zone and helps to solve the problem of $\mathrm{Mg}$ defiance in crops but due to harvesting of this type of water from the underground increases the $\mathrm{Mg}$ concentration in surface water bodies through the runoff from agricultural fields this increased concentration of magnesium will cause scouring and diarrhea in livestock.

\section{Salinity status of water in agroecosystems}

We have also used US Salinity Laboratory hazard standards (Richards 1954), constructed based on the correlations of sodium absorption ratio and electrical conductivity, which indicates that all surface water shows significant variation from C1-S1 (Low-salinity water and low sodium hazard) to C3-S1 (High-salinity water and low hazard sodium) category (Fig. 4 and Supplementary Table 5a and $5 \mathrm{~b}$ ). But most of the urban water falls in the C3-S1 (High-salinity water and low hazard sodium) category followed by transition C2S1 (Medium-salinity water and low sodium hazard) and rural (C1-S1) (Low-salinity water and low sodium hazard) (7 out of 10 samples) but 3 samples in rural zone come under C3-S1 (High-salinity water and low hazard sodium) category. From the USSLH diagram (Fig. 4 and Supplementary Table 5a and 5b) it can be seen that sodium hazard is more in urban area compared to rural and transition zone, which is mainly due to higher sewage draining into 
water bodies compared to transition and rural zone. Use of urban surface water without proper treatment and soil management practices will lead to soil pollution and increases the salinity and alkalinity which make these vital resources unfit for cultivation of crops in the urban agro-ecosystems.

\section{References}

Anonyms, 2017. Parisaramahiti (ENVIS Centre Karnataka), Government of Karnataka, https://www.karnataka.gov.in/Parisara mahiti/Pages/Lakes-of-Bangalore.aspx (accessed on 03/04/2019)

Anonyms, 2018. Fact sheets on drinking water. WHO, https://www.who.int/news-room/factsheets/detail/drinking-water accessed on $20 / 03 / 2019$.

Anonyms, 2019. Water Quality Evaluation. FAO,

http://www.fao.org/3/t0234e/t0234e01. htm accessed on 3/03/2019.

BIS, 1998. Specifications for drinking water. New Delhi: Bureau of Indian Standards.

BIS, 2012. Specifications for drinking water. New Delhi: Bureau of Indian Standards.

FIPPS, G., 2003. Irrigation Water Quality Standards and Salinity Management Strategies. Available electronically from http: / /hdl.handle.net /1969.1 187829.

Goswami, S., 2017. About 85 per cent of Bengaluru's water bodies severely polluted: study, Down to earth. https://www.downtoearth.org.in/news/ water/about-85-per-cent-of-bengalurus-water-bodies-severely-pollutedstudy-59189 (accessed on 20/03/2019).

Gupta, S., Maheto, A., Roy, P., Datta, J.K., Saha, R.N. 2008. Geochemistry of groundwater Burdwan district, West
Bengal India. Environ Geol 53:12711282.

Hoffmann, E. M., Jose, M., Nölke, N. and Imöckel, T., 2017. Construction and Use of a Simple Index of Urbanization the Rural-Urban Interface of Bangalore, India. Sustainability, 9, 2146.

Hunse, T. M., 2008. Ground Water Information Booklet, Bangalore Urban District, Karnataka, 1-26. Sudhira, H. S. 2006. Urbanization in Bangalore. 163. http://wgbis.ces.iisc.ernet.in/ energy/lake2006/programme/program me/proceedings/Presentations/Lake $\% 2$ 02006\%20\%20Presentations/30\%20De c\%202006/Session\%20XI/Sudhira/Urb anisation\%20in\%20Bangalore.pdf (accessed on 20/03/2019)

NitiAayog, 2018. Composite Water Resources Management index. Government of India publication. http://niti.gov.in/writereaddata/files/do cument_publication/2018-05-18-

Water-Index-Report_vS8compressed.pdf accessed on 20/03/2019.

Pandit, A.K., 2002. Topical evolution of lakes in Kashmir Himalaya. In: Pandit AK (ed) Natural resources of western Himalaya. Valley Book House, Srinagar J\&K, pp 213-242.

Purandara, B.K., Varadarajan, N. and Jayashree, K., 2003. Impact of sewage on ground water: a case study. Poll Res, 22(2):189-197.

Ramachandra, T.V., Bharath, A.H. and Durgappa, D.S., 2012. Insights to urban dynamics through landscape spatial pattern analysis. Int. J Applied Earth Observation and Geoinformation, 18; 329-343.

Rao, G.S. and Rao, G.N., 2010. Study of groundwater quality in greater Visakhapatnam city, Andhra Pradesh (India). J Environ SciEng, 52(2); 137- 
146.

Ravikumar, P.,Mehmood, M. A., and Somashekar, R. K., 2013. Water quality index to determine the surface water quality of Sankey tank and Mallathahalli lake, Bangalore urban district, Karnataka, India, Applied water sciences, 3; 247-261.

Mirabbasi, R., Mazloumzadeh, S.M. and Rahnama, M.B., 2008. Evaluation of Irrigation Water Quality Using Fuzzy Logic. Research Journal of Environmental Sciences, 2; 340-352.

Tekin, K. and Lyman S.W., 2006. Leaching Requirements to Prevent Soil Salinization, Journal of Applied Sciences, 6(7): 1481-1489.

WHO, 2004. Guidelines for drinking-water quality, World Health Organization, 3rd edn, vol 1. Recommendations. Geneva, Switzerland, pp 515

WWAP (UNESCO World Water Assessment Programme), 2019. The United Nations World Water Development Report 2019: Leaving No One Behind. Paris, UNESCO.

WWAP (United Nations World Water Assessment Programme), 2018. The United Nations World Water Development Report 2018: NatureBased Solutions for Water. Paris, UNESCO.

UN DESA (United Nations Department of Economic and Social Affairs), 2018. Revision of World Urbanization Prospects, Population Division of the
United Nations Department of Economic and Social Affairs, Multimedia Library, https://www.un.org/development/desa/ publications/2018-revision-of-worldurbanization-prospects.html accessed on 8-17-2019.

Angel, S., Sheppard, S. C. and Civo, D. L., 2005. The Dynamics of Global Urban Expansion. Washington, DC, USA, pp. 1-125.

Seto, K. C., Parnell, S. and Elmqvist, T., 2013. A global outlook on urbanisation. In: Elmqvist, T. et al., (eds.) 2013. Urbanisation, Biodiversity and Ecosystem Services: Challenges and Opportunities. A Global Assessment. DOI 10.1007/978-94-007-7088-1_1.

Sorensen, A. and Okata, J., 2010. Megacities: Urban Form, Governance and Sustainability, Springer, New York, NY, USA.

Taubenböck, H., Wegmann, M., Berger, C., Breunig, M., Roth, A. andMehl, H., 2008. Spatiotemporal analysis of Indian mega cities. In: Proceedings of the International Archives of the Photogrammetry, Remote Sensing and Spatial Information Sciences (ISPRS). Vol. XXXVII. Part B2. Beijing, pp. 75-82.

Narayana, M. R., 2011. Globalization and urban economic growth: Evidence for Bangalore, India. Int J Urban Reg Res, 35: 1284-1301.

\section{How to cite this article:}

Dhanush, C. and Devakumar, A. S. 2019. Consequences of Urbanization on Surface Water bodies Water Quality along the Rural-Urban and Transition zones of Bengaluru. Int.J.Curr.Microbiol.App.Sci. 8(12): 2014-2030. doi: https://doi.org/10.20546/ijcmas.2019.812.239 